\title{
GOVERNMENT IMMUNITY FROM DISCOVERY
}

\author{
RAOUL BERGER广 and ABE KRASH*
}

No reform initiated by the Federal Rules of Civil Procedure was more enthusiastically acclaimed than its machinery for pre-trial discovery. ${ }^{1}$ Discovery was to abolish trial by ambush, to banish "the 'old fixed principle' of keeping an opponent in the dark" and the "sporting theory of justice."? Henceforth, the ends of justice were to be promoted by pretrial disclosure. ${ }^{3}$

No one has more eagerly resorted to the discovery machinery than the Government; ${ }^{4}$ no one has been more grudging in making it reciprocally available. ${ }^{5}$ Viewed against traditional notions of fair play, it is not surprising that Government attempts to "thwart the efforts of a plaintiff" to obtain disclosure have been judicially labeled as "unseemly," as an "unjust and tyrannical exercise of power."

$\div$ Member of the District of Columbia and Illinois Bars.

* Member of the District of Columbia Bar.

1. FED. R. Civ. P. 26-37. This article deals with two of the pre-trial instruments of discovery: the subpoena-deposition procedure under Rules 26 and 45 , and discovery under Rule 34.

Facts are also elicited and the issues narrowed before trial by admissions, interrogatories, and the pre-trial conference. On discovery in general see Holtzoff, Instruments of Discovery Under the Federal Rulles of Cizil Procedure, 41 Mrrca. L. Rev. 205 (1942) ; Pike \& Willis, Federal Discovery in Operation, 7 U. OF Crr. L. Rev. 297 (1940); Sunderland, Discovery Before Trial Under the New Federal Rules, 15 Tews. L. Rev. 737 (1939).

For pre-Rules discovery see Ragland, Discovery Before Trial (1932); for changes wrought by the Rules see 4 MLORE's FederAl PrActice 2423-33 (2d ed. 1950).

2. Hoffman v. Palmer, 129 F.2d 976, 997 (2d Cir. 1942); see also Hicliman v. Taylor, 329 U.S. 495, 507 (1947).

3. See Laverett v. Continental Briar Pipe Co., 25 F. Supp. S0, 83 (E.D. N.Y., 1938); Laws, J., Pre-Trial Procedure, 1 F.R.D. 397, 399 (1940). It has been asserted that a failure to disclose "prevented plaintiff from having a fair trial." Burton v. Weyerhzeuser Timber Co., 1 F.R.D. 571,574 (D. Ore. 1941).

4. See, c.g., the sweeping discovery order sought by the Government in United States v. National City Bank of New York, 40 F. Supp. 99 (S.D. N.Y. 1941 ).

5. "In all these cases, particularly in those seeking injunctive relief, the Goacriment expects the utmost cooperation of the defendants or even prospective defendants in placing their files and records, ranging over periods of years, at the disposal of its agents. When objection is encountered, the widest gise is made of the processes of the courts. A justified criticism of the Government is, however, that it is not so generous in reciprocating. Thus, the Government stands on the liberal rules which allow them to plead the facts generally and resist at all stages, ezery attempt to compel them, through bills of particulars, to supply data which would give the defendants a definite idea of the line of attack which they may expect at the trial. Judges, in our Circuit, including myself, have been rather generous in compelling disclosure, so as to chamel the inquiry." Yankwich, Obscriations on Anti-Trust Procedures, 10 F.R.D. 165, 168 (1950). (Emphasis supplied throughout).

The cases compelling the Government to disclose, hereinafter cited, illustrate that a battle has been required at every step.

6. Cresmer v. United States, 9 F.R.D. 203 (E.D. N.Y., 1949).

7. United States v. General Motors Corp., 2 F.R.D. 528,530 (N.D. IIl., 1942). 
Mitchell said, "it ought not to be necessary to resort to discovery against the government," for "the government litigates with its citizens and ought to be frank and fair and disclose all the facts."

The mounting volume of litigation in which the Government is involved, coupled with the increasing tendency to suppress information under the guise of national security, ${ }^{0}$ presents a problem of growing importance in the relationship between state and citizen. When the Government is confronted by some industrial giant, there is relative equality in such litigation. But too often, it is the little man who is overwhelmed by the Government's vast resources. For example, seizures of American property by the Alien Property Custodian on the alleged ground that it is enemy-owned pauperize the claimant at the outset, ${ }^{10}$ so that he is unable to duplicate the extensive trial preparation undertaken by the Government. Similarly, injustice may be done to litigants of small means prosecuting claims under the Federal Tort Claims and Suits in Admiralty Acts if the Government withholds the written statements of witnesses to the accident. ${ }^{11}$ Government consent to suit in such cases may become meaningless if linked with a right to suppress facts in its possession. ${ }^{12}$

These problems have received surprisingly little critical attention, and were left dangling in air this year by the Supreme Court in its little-noticed

8. Remarks as Chairman of the Advisory Committee to the Supreme Court on the Federal Rules of Civil Procedure, at Proceedings of the Inst. of the Am. Bar Ass'n., F.R.C.P., WASH., N.Y. 333-334 (1938). The rule governing criminal prosecutions might well be given wider scope: "The primary duty of a lawyer engaged in a public prosecution is not to convict but to see that justice is done. The suppression of facts . . . capable of establishing the innocence of the accused is highly reprehensible." Amcrican Bar Associotion Canons of Ethics, Canon No. 5. See also Woodruff v. Trapnall, 10 How. 190, 20\% (U.S. 1850) (Government committed to a higher degree of fairness than a private litigant).

9. Few cases actually involve military or diplomatic secrets; normally litigants seck written statements secured by the government from third parties which would be ordered produced forthwith if held by a private individual. Ordinarily military or diplomatic secrets are privileged. 8 WIGMORE, EVIDENCE $\$ 2378$ A (3d ed. 1940).

The sharply debated disclosure problem in loyalty proceedings involves a question different from that under discussion. In such cases the documents are in the possession of those who judge, but are withheld from the defendant. The question here considered is whether the federal government can withhold from federal judges the power to inspect relevant documents and to decide if they should be divulged to litigants.

10. Cf. McGrath v. Manufacturers Trust Co., 338 U.S. 241, 248 (1949).

11. Of the twenty-seven civil cases reported as of September, 1950, in which discovery was sought against the federal government, eight involved negligence claims. Thero were five antitrust cases, three Fair Labor Standards Act procecdings, three war risk insurance cases, and one case each involving price control, Food and Drug Act, Interstate Commerce Act, alien property, patent infringement, taxation, and an informer's action.

12. The government's consent to suit, Judge Rifkind has declared, ". . . amounts to an endorsement of the [action] with the sovereign's command 'Soit droit fait al partie.' [Let right be done to the party.] But right cannot be done if the government is allowed to suppress the facts in its possession." Bank Line v. United States, 76 F. Supp. 801, 804 (S.D. N.Y., 1948). 
per curiam decision in United States v. Cotton Valley Oil Operators Committee. ${ }^{13}$ Defendants were charged with violating the Sherman Act. Agents of the Federal Bureau of Investigation examined defendants' files and interviewed officers and employees of the defendants as well as other persons. The defendants thereupon moved for discovery under Rule 34 to require the Attorney General to produce all FBI reports, and all communications and replies thereto received by the Department of Justice relating to the challenged activities of the defendants. ${ }^{14}$

In opposing the motion, the Government maintained that it was "exclusively within the authority of the Attorney General to determine whether such documents" were privileged. ${ }^{10}$ The trial judge directed the Government to submit the documents to the court for its determination as to which, if any, were privileged and which should be supplied defendants. When the Government refused to comply with this ruling, the complaint was dismissed. ${ }^{16}$ The Supreme Court, equally divided, affirmed the decision per curiam.

The failure of the Court to reach any decision in the Cotton Valley case leaves the door open for continuing controversy over the scope of the Government's privilege. The contention that a Government agency may decide for itself what documents it will divulge to the court is tantamount to a claim of blanket immunity from discovery procedure. If the court is not permitted to pass on a claim of privilege, "discovery" against the Government comes to mean that those facts will be disclosed which the Government wishes to disclose. To all litigants in need of facts in the Government's possession this problem is acute. It is our purpose to examine the basic considerations which furnish a guide to judgment on this and related issues.

\section{The Governatent as a Litigant}

Discovery may be sought in civil cases to which the Government is a party, in civil actions to which the Government is a stranger, and in criminal prosecutions. In the criminal cases, the courts, lacking the discovery provisions of the Rules of Civil Procedure, have drawn upon principles analogous to waiver." It was soon perceived that this was but a "useful fiction." The Government "waives" nothing by bringing a criminal prose-

13. 339 U.S. 940 (1950).

14. Brief for the United States, Statement as to Jurisdiction, pp. 3-4, United States v. Cotton Valley Operators Committee, 339 U.S. 940 (1950).

15. Id. at 4-5.

16. United States v. Cotton Valley Operators Committee, 9 F.R.D. 719 (W.D. La. 1949).

17. "The government must choose; either it must leave the transactions in the obscurity" from which a trial may draw them, or it must expose them." United States v. Andolschel, 142 F.2d 503, 506 (2d Cir. 1944). See also United States v. Grayson, 166 F.2d 863, 870 (2d Cir. 1948); United States v. Beekman, 155 F.2d 580, 584 (2d Cir. 1946); United States v. Krulewitch, 145 F.2d 76, 79 (2d Cir. 1944). 
cution to enforce its laws. But the fiction supplied a convenient rationalization for an underlying policy: no one should be convicted of a crime without having access to material which might exculpate him. ${ }^{18}$

Principles of waiver had earlier been applied in civil actions where the Government was plaintiff, ${ }^{10}$ and were subsequently applied to the Government as defendant in Bank Line v. United States. ${ }^{20}$ Balancing the public interest in assuring justice to litigants against the Government's interest in preserving the secrecy of its housekeeping records, the court inched beyond the criminal and civil-plaintiff cases. Whatever the force of "waiver" when the Government sued or prosecuted, it plainly waived nothing when made a defendant. A different rationalization was therefore necessary. Sovereign immunity would normally prevent suits against the Government. In consenting to suit, Congress could have circumscribed consent by immunity against disclosure. But since no limitations had been attached to the consent, the court was free to assume that no limitations were intended.

The court, however, was apparently unaware that the Congress had moved beyond such implications and made the Government subject to discovery requirements. For the Rules were intended to and do apply equally to the Government and private litigants. ${ }^{21}$ Statements of the

18. See United States v. Watkins, 67 F. Supp. 556, 561 (S.D. N.Y. 1946).

19. A Government officer who sues "must be held to have waived any privilege which he might otherwise have had, to withhold testimony... [ [He] must either give up his privilege to withhold pertinent evidence or he must abandon his suit." Fleming v. Bernardi, 1 F.R.D. 624, 625 (N.D. Ohio 1941) ; and see Bowles v. Ackerman, 4 F.R.D. 260 (S.D. N.Y. 1945). Other cases in which discovery was granted where Government was plaintiff : United States v. New York, C. \& St.L. Ry., 8 F.R.D. 258 (N.D. Ohio 1948); Walling v. Richmond Screw Anchor Co., 4 F.R.D. 265 (E.D. N.X. 1943); United States v. General Motors Corp., 2 F.R.D. 528 (N.D. IIl. 1942).

20. 76 F. Supp. 801,804 (S.D. N.Y. 1948). Other cases in which discovery was granted where Government was defendant: Brauner v. United States, 19 U.S.L. WEEK 2036 (D.C. Pa. 1950) ; Henz v. United States, 9 F.R.D. 291 (N.D. Cal. 1949); Cresmer v. United States, 9 F.R.D. 203 (E.D. N.Y. 1949); Societe Internationale Pour Participations Industrielles et Commerciales, S. A. v. Clark, 9 F.R.D. 263 (D.C. D.C. 1949); O'Neill v. United States, 79 F. Supp. 827 (E.D. Pa. 1948) ; Wunderly v. United States, 8 F.R.D. 356 (E.D. Pa. 1948) ; Cogdill v. T.V.A., 7 F.R.D. 411 (E.D. Tenn. 1947) ; Brewer v. Hassett, 2 F.R.D. 222 (D. Mass. 1942); United States v. Smith, 117 F.2d 911 (9th Cir. 1941); Galanos v. United States, 27 F. Supp. 298 (D. Mass. 1939).

21. "Rules 1 and 81 carefully provide that they shall apply to all stits of a civil nature, whether cognizable as cases at law or in equity, except those specifically excepted; and the character of the proceedings which it was thought necessary to except by express statement in Rule 81, as well as the language of these rules, shows that the new 'civil action' includes actions against the United States." Sherwood v. United States, 112 F.2d 587, 590 (2d Cir. 1940).

"To hold that the rules do not apply to the United States except where it is particularly mentioned would lead to absurd results." United States v. General Motors Corp., 2 F.R.D. 528, 530 (N.D. I11. 1942). 
draftsmen contemporaneous with its adoption, ${ }^{22}$ the structure of the Rules, ${ }^{23}$ and the decisions, ${ }^{24}$ have conclusively established that the Government is to be treated no differently than a private litigant, ${ }^{25}$ and is bound by every provision of the Rules except where expressly exempted. ${ }^{20}$ The exemption granted from some of the rules is notably absent in the discovery provisions. It is faulty analysis to pose the problem in terms of whether the Rules enlarged the consent to be sued."7 Analysis must begin with the fact that such consent places the Government in the position of an ordinary litigant except to the extent that it is expressly exempted from the Rules. And once there is consent the provision granting that consent should be construed to accomplish its purpose. ${ }^{28}$

In the Cotton Valley and other recent cases the Government has claimed the right to determine for itself, without judicial interference, what documents in its possession are privileged so as to be exempt from discovery. The basis of the claim is threefold: a reading of Marbury v. Madison and the Trial of Aaron Burr; a construction of Section 22 of Title 5 of the United States Code; and an alleged necessity for secrecy plus a faith in

22. At the American Bar Association Institute on the Federal Rules, Charles E. Clark, reporter for the Advisory Committee, declared that ". . . it was our theory that except as we made special provisions these rules apply to the United States as a litigant as much as to anyone else" Proceedings of the Institute of the Ars. BAr Ass'r., F.R.C.P., WASE., N.Y. 50 (1938).

Former Attorney General William D. Mfitchell said that "... these rules put the government on the same basis as any other litigant [and] in the absence of any provision exempting the government from these rules they apply."

Mitchell then noted that Rule 33 which is drawn in the same general terms as the discovery provision, Rule 34, is applicable to the United States. Id. at 333.

And Prof. Dawson added: "Rule 34 provides for the discovery and production of documents and things for inspections. I should say that it does apply to the United States subject to the usual limitations for privileged or confidential documents." Id. at 105.

23. There are nine sections in the rules according special treatment to the United States-Rules $4(4) ; 12(\mathrm{a}) ; 25(\mathrm{~d}) ; 37(\mathrm{f}) ; 39(\mathrm{c}) ; 54(\mathrm{~d}) ; 55(\mathrm{c}) ; 62(\mathrm{c}) ; 65(\mathrm{c})$. These cxceptions would be superfluous if the unqualified provisions did not apply.

24. See United States v. Yellow Cab Co., 338 U.S. 338, 341 (1949) holding that "[i]t ought to be unnecessary to say that Rule 52 [which provides that findings of fact shall not be set aside on appeal unless clearly erroneous] applies to appeals by the government as well as to those by other litigants. There is no exception which permits it . . . to come to this court ... for a trial de novo." Cf. United States v. General Motors Corp., 2 F.R.D. 528, 530 (N.D. Ill. 1942) : "If Rule 33 is not applicable to the United States . . . it would have been expressly stated that the United States was not subject to Rule 33."

25. See Walling v. Richmond Screw Anchor Co., 4 F.R.D. 265 (E.D. N.Y. 1943).

26. Like every litigant, the government may of course invole an applicable privilege. Rule 26 (b) provides that "the deponent may be examined regarding any matter, not prizileged." Rule 34 states that any party may be ordered "to produce ... any designated documents, papers, books, accounts, letters, photographs, objects or tangible things, not privileged."

27. See O'Reilly, Discovery Against the United States: A New Aspect of Sotcrcign Immunity? 21 N.C.L. Rev. 1, 3-5 (1942).

28. Federal Housing Administration v. Burr, 309 U.S. 242, 245 (1940). 
administrative expertise to determine what may properly be divulged. The three parts of this argument may be examined separately.

\section{The Historical Claim of Executive Immunity}

The Attorney General maintains that, "personifying the executive branch of the Government, [he] is free to refuse disclosture of any evidence in his possession, regardless of its character, for any reason which may seem to him sufficient."20 This contention departs from the position earlier taken by the Attorney General, ${ }^{30}$ and it reaches deep into our history for its foundation. In the Cotton Valley case, the Government rested its claim on a colloquy in Marbury v. Madison, ${ }^{31}$ and on the fact that in the Burr case President Jefferson "ignored the subpoena and directed the United States Attorney to produce only such portions of the letter as he deemed not to be confidential."'32

Neither half of the argument will bear analysis. The Marbury colloquy, repeatedly pressed on Chief Justice Marshall during the $B u t r r$ trial, ${ }^{3 \mathrm{~b}}$ was rejected by him on the ground that it concerned only communications between the President and his Secretary of State, ${ }^{34}$ which were in fact "confidential." Thus Marshall confined the colloquy to "confidential" executive communications.

Further, it is hardly accurate to state that "Jefferson ignored the subpoena" which issued in the Burr case. Chief Justice Marshall issued a subpoena commanding President Jefferson to appear and to bring cer-

29. O'Neill v. United States, 79 F. Supp. 827, 830 (E.D. Pa. 1948). This is spelled out in the Government's Cotton Valley brief, supra note 14, at 5-8.

30. Mr. Justice Clark, then Attorney General, stated in $1947:$ "It is important that there should be no appearance of arbitrary refusal to comply with the subpoena [to produce documents] and that every respect should be paid to the court's order. Thereforc, the officer or employee should, unless directed to the contrary by the Attorney General, bring with him the records and documents which are called for by the subpoena even though the Department takes the position that it is not necessary to produce them. . . . If questioned the officer or employee should state [to the court] that the material is at hand and can be submitted to the court for determination as to its materiality in the case and whether in the best public interests the information should be disclosed." Dept. Justice Order No. 3229, Supp. No. 2, June 6, 1947.

31. 1 Cranch 137, 144-145 (U.S. 1803) : "The court said that if Mr. Lincoln [Attorney General] wished time to consider the answers he should make, they would give him time; but they had no doubt he ought to answer. There was nothing confidential required to be disclosed. If there had been he was not obliged to answer it; and if he thought that any thing was communicated to him in confidence he was not bound to disclose it; nor was he obliged to state any thing which would criminate himself; but that the fact whether such commissions had been in the office or not, could not be a confideutial fact; it is a fact which all the world have a right to know. If he thought any of the questions improper, he might state his objections."

32. Brief, supra note 14 , at $5-6$.

33. Aaron Burr's Trial, I RobERtson's RePt. 117 (1875) ; II RonerTSON's RErT. 521, 524, 526 (Phila. 1808).

34. II ROBERTSON'S REPT. 527 (1808). 
tain letters, documents, and copies of orders and instructions given by him to the armed services respecting Aaron Burr. The power to subpoena the President was conceded; Government counsel William Wirt merely argued that the documents sought were not relevant and that a subpoena duces tecum was addressed to the discretion of the court. ${ }^{35}$ Marshall took the legality of the subpoena for granted. A subpoena duces tecum could issue, he said, "to any person to whom an ordinary subpoena may issue, directing him to bring any paper of which the party praying it has a right to avail himself as testimony."36 This was compulsory production of documents by the Government, which lies at the root of the discovery as well as the subpoena power.

It is true that Jefferson asserted the power to withhold, ${ }^{37}$ but nonetheless he fully complied with the subpoena. ${ }^{38}$ He produced all the documents demanded except one, a letter from General Wilkinson, and he left it to Government Counsel, George Hay, to withhold "communication of any parts of the [Wilkinson] letter which are not directly material for the purposes of justice." 39 Hay emphasized that he was willing to disclose the entire letter to the court, and leave it to the court to suppress so much of the letter as was not material to the case. ${ }^{40}$ This was re-emphasized in his re-

35. I ROBERTSON'S REPT. 121 (1875).

36. Id. at 178. As to the court's "discretion," Mfarshall said that "[T]he court has no right to refuse its aid to motions for papers to which the accused may be entitled, and which may be material in his defense." Id. at 180 . Lest it be thought the rule in civil cases may be narrower, note Marshall's statement: "If this might be likened to a civil case, the law is express on the subject. It is that either party may require the other to produce books or writings in their possession or power, which contain evidence pertinent to the issue" II ROBERTSON'S REPT. 534 (1808).

37. The Jefferson correspondence concerning the subpoena is collected in 9 Fond, WRITINGS OF THOAIAS JEFFERSON 55-62 (1892-99).

38. Jefferson, on June 12, 1807, wrote George Hay, the United States District Attorney, that he had delivered the papers to the Attorney General, and instructed the War and Navy Departments to review their files with a view to compliance. I Ronertso:s's REm. 211 (1875). On June 17, 1807, Jefferson wrote Hay that "[t]he receipt of these papers [by Hay] has I presume, so far anticipated, and others this day forwarded will have stibstantially fulfilled the object of a subpoena from the District Court of Richmond. . . ." $I d$. at 265 .

When Jefferson learned that the Attorney General did not have the Willinson letter subpoenaed by Burr, he wrote Hay on June 23, 1807: "No researches shall be spared to recover this letter and if recovered it shall immediately be sent on to you." 9 Fond, WRITINGS of ThOasas JEFFERSON 61 (1S92-99). Hay advised the court that "When we receive General Wilkinson's letter, the return will be complete" I Rosertso:r's Rerr. 267 (1875).

39. I Ropertson's REPt. 211 (1875).

40. Thus Hay said: "The application made by the defendant is that testimony which concerns himself should be adduced; that what tends to his oun just defense and creulpotion may be brought forward. Is it right that he should hate more? Is it proper, fair or right that he should have the liberty of going through the whole letter, os zwell those farts which do not relate to him as those which do, for the purpose of making uniavorable impressions on the public mind, ... making public confidential communications respecting 
turn to the subpoena duces tecum wherein he returned a copy of the letter

"excepting such parts thereof as are, in my opinion, not material for the purposes of justice, for the defence of the accused, or pertinent to the issue now about to be joined. . . . The accuracy of this opinion I am willing to refer to the judgment of the court, by submitting the original letter to its inspection." 41

Far from asserting a claim of absolute privilege, therefore, the Government was perfectly willing to leave it to the court to determine whether portions of the letter were in fact privileged. It insisted only that the portions so adjudged should be withheld from the defendant. To this the defendant objected that the court could not judge whether the confidential portions were relevant to the defense until that defense was fully disclosed, and that defendants were not required to make such disclosure until they had put in their case. ${ }^{42}$

It was on this state of facts that Chief Justice Marshall ruled. He said

"That the president of the United States may be subpoenaed, and examined as a witness, and required to produce any paper in his possession, is not controverted. . . . The president, although subject to the general rules which apply to others, may have sufficient motives for declining to produce a particular paper, and those motives may be such as to restrain the court from enforcing its production. . . . I can readily conceive that the president might receive a letter which it would be improper to exhibit in public, because of the manifest inconvenience of its exposure. The occasion for demanding it ought, in such a case, to be very strong, and to be fully shown to the court bcforc its production could be insisted on." 43

And, referring to private letters sent to the President respecting matter of public concern, Marshall stated that they

"ought not on light ground to be forced into public vicw. Yet it is a very serious thing, if such letter should contain any information material to the defence, to withhold from the accused the power of making use of it. . . . I cannot precisely lay down any general rule for such a case. Perhaps the court ought to consider the reasons, which would induce the president to refuse to exhibit such letter as conclusive on it, unless such letter could be showen to be absolutcly nccessary in the defence. The president may himself state the particular reasons which may have induced him to withhold a paper, and the court would unquestionably allow full force to those reasons. At the

private characters, and thereby producing controversies and violent quarrels. $I$ zeish thc court to look at the letter and see whether it do not contain what ought not to be submitted to public inspection." II RoBERTSON's REPT. 509 (1808).

41. Id. at 513-514.

42. Id. at 516 .

43. Id. at 535-536. Emphasis supplied. 
same time the court could not refuse to pay propar attention to the affidavit of the accused. But on objections being made by the president to the production of a paper, the court would not proceed furlher in the cause without such an affidavit as would clcarly show the papor to be essential to the justice of the case. . . . [T]o induce the court to take any definitive and decisive step with respect to the prosecution, founded on the refusal of the president to exhibit a paper, for reasons stated by himself, the materiality of that paper ought to be shown."4k

And he finally stated that

"I do not think that the accused ought to be prohibited from seeing the letter. . . ."45

Such is the historical background of the Government's argument for immunity from discovery procedure. The subpoena to Jefferson was not "ignored," nor was discretion as to disclosure left in the hands of the executive. Instead of supporting the Government's contentions, the Burr case shows that Marshall forthrightly asserted and exercised the judiciary's power to decide whether the executive claim of privilege was meritorious and decided in the case before him that the claim had no merit. ${ }^{10}$

Ultimately the claim of executive immunity from discovery rests on the separation of powers. Pressed to its logical conclusion that argument would immunize executive agencies from suits altogether. Yet it is undebatable that Congress may authorize suits against executive agencies, the separation of powers notwithstanding. ${ }^{17}$ Given the power to bring administrators into court by summons, the lesser power to subpoena or to compel them to produce documents logically follows. That the United

44. Id at 536. Emphasis supplied.

45. Id. at 537. Earlier in the trial Marshall ruled "That there may be matter, the production of which the court would not require is certain; but that, in a capital case, the accused ought, in some form, to have the benefit of it, if it atere really cesmitiol to his defense, is a position which the court would very reluctantly deny. . . . There is certainly nothing before this court which shows that the letter in question contains any matter the disclosure of which would endanger the public safety.

"If it does contain any matter which it would be imprudent to disclose, which it is not the wish of the Executive to disclose, such matter, if it be not immediafly and esscntially applicable to the point, will of course be suppressed. . . . Everything of this kind, however, will have its due consideration on the return of the subpoena." I Rosentso:t's Repr. 183-184 (1875).

46. The claim of "executive" immunity is but a variant of "sovereign" immunity, which is in "current disfavor." RFC v. J. G. Mfenihan Corp., 312 U.S. 81 (1941); Federal Housing Administration v. Burr, 309 U.S. 242 (1940); Keifer \& Keifer v. RFC, 306 U.S. 381 (1939).

47. "[N]o suit can be maintained against the United States . . without express authority of Congress. . . . Neither the Secretary of War nor the Attorney General nor any subordinate of either has been authorized to waive the exemption of the United States from judicial process, or to submit the United States [to suit]." Stanley v. Schwalby, 162 U.S. 255, 270 (1896); United States v. Clarke, 8 Pet. 436, 444 (U.S. 1834). 
States enjoys no immunity as plaintiff which is denied to it as defendant seems clear, particularly since Congress has undoubted power to prescribe how litigants must proceed. No one, as Marbury v. Madison demonstrates, was more sensitive to the separation of powers than Marshall; his omission to mention that problem in the Burr opinions strongly militates against an argument that separation of powers demands executive immunity.

\section{The Claim of Statutory Immunity}

The Government has also repeatedly claimed a statutory immunity from the discovery rules by virtue of Section 22 of Title 5 of the United States Code $;^{48}$ and it argued in the Cotton Valley case that Section 22 constituted Congressional recognition of the executive privilege. ${ }^{40}$ Section 22 reads as follows:

"The head of each department is authorized to prescribe regulations, not inconsistent with law, for the government of his clepartment, the conduct of its officers and clerks, the distribution and performance of its business, and the custody, use, and preservation of its records, papers, and property appertaining to it." 50 (Emphasis stupplied).

The government's contention that this section authorizes federal agencies to claim immunity from discovery ignores the emphasized phrase. If regulations promulgated under Section 22 cannot be "inconsistent with law," they cannot be "inconsistent with" the Rules, which have the force of law." The discovery rules do not exempt the United States. The authority to prescribe regulations "not inconsistent with law" therefore does not confer

48. United States v. Kohler, 9 F.R.D. 289 (E.D. Pa. 1949); O'Neill v. United Statc9, 79 F. Supp. 827 (E.D. Pa. 1948); Wunderly v. United States, 8 F.R.D. 356 (E.D. Pa. 1948); Zimmerman v. Poindexter, 74 F. Supp. 933 (Hawaii 1947); United States v. Schine Chain Theatres, 4 F.R.D. 108 (W.D. N.Y. 1944); Walling v. Comet Carriers, 3 F.R.D. 442 (S.D. N.Y.1944).

49. Brief, supra note 14, at 6 . For a discussion of the relation of Section 22 to the discovery rule, see Note, 58 YALE L.J. 993 (1949).

50. 5 U.S.C. $\$ 22$ was created by the revisers of the federal statutes in 1875 by combining two groups of acts. One group, dating from 1789, authorized the heads of newly established agencies of the government "to have the custody and charge of all records, books, and papers" pertaining to their official duties then in the possession of others. Sec, e.g., 1 StAT. 28 (1789). Another series had authorized department heads to "makc all necessary rules and regulations for the government and management of their agencies." See, e.g., 16 STAT. 163 (1870). It is this blend of "housekeeping" statutes which the Attorney General cites as the statutory source of his exclusive authority to withhold documents relevant to litigation.

51. Beasley v. United States, 81 F. Supp. 518, 527 (E.D. S.C. 1948) ; C. J. Wieland \& Son Dairy Products Co. v. Wickard, 4 F.R.D. 250, 252 (E.D. Wis. 1945); United States v. Schine Chain Theatres, 2 F.R.D. 425,427 (W.D. N.Y. 1942). 
an administrative power to carve out an exemption from rules having the force of law any more than from the coverage of any other statute. ${ }^{\mathrm{E}}$ ?

Furthermore, under a familiar doctrine of statutory construction, Congressional approval ${ }^{53}$ of the Rules exhibits an intention to withhold governmental immunity from discovery. The exemption expressly granted the United States from certain of the Rules was witheld in the discovery provisions. The pattern of express exemption thus established precludes the possibility of implied exemptions elsewhere. The omission of an express exemption in the discovery rules must therefore be considered a studied omission which would be made futile if Section 22 were interpreted as conferring an exemption. 54 Lacking express provision for absolute executive privilege, the Rules are equivalent to a Congressional adoption of Marshall's view that there is none.

As the Government has recognized, most courts follow this interpretation, and insist on their right to determine the scope of the Government

52. A departmental non-disclosure regulation must yield to a parallel Admiralty Rule. O'Neill v. United States, 79 F. Supp. 827, 830 (E.D. Pa. 1948); and see Brauner v. United States, 19 U.S.L. WEER 2036 (E.D. Pa. 1950).

It was likewise held in United States v. Schine Chain Theatres, 4 F.R.D. 108, 109 (W.D. N.Y. 1944) that the non-disclosure regulation of the Department of Justice ". . . does not prevent the court from ordering the production of files of the Department of Justice in all cases. There may be certain of such files which are entirely privileged and others which are not." See also Zimmerman v. Poindester, 74 F. Supp. 933, 935 (Hawaii 1947) ("the clear mandate that all executive regulations be 'not inconsistent with law' circumscribes the power of the entity prescribing the regulation under consideration, and operates to make the applicability and enforceability of a specific department regulation a judicial question for ultimate decision by the court.").

Cases to the contrary such as Walling v. Comet Carriers Inc., 3 F.R.D. 442 (S.D. N.Y. 1944), and United States v. Brooks, 51 F. Supp. 974 (D. N.J. 1943), overlook the paramount force of the Rules with respect to any regulation promulgated under 5 U.S.C. $\S 22(1948)$.

The O'Neill case was distinguished on the ground that the Government was acting in a "proprietary" as differentiated from a "sovereign" capacity in United States v. Kohler Co., 9 F.R.D. 289 (E.D. Pa. 1949). The Rules recognize no such distinction. It is moreover an "artificial distinction" which should not be extended. Cf. Pike \& Fischer, Discozery Against Federal Administrative Agcucies, 56 HARv. L. Rev. 1125, 1129 (1943).

53. The approval is traced in United States v. Brandt, 8 F.R.D. 163, 165 (D. Mont. 1948).

54. That the power to make regulations "not inconsistent with law" does not stretch to creation of an absolute privilege may be further deduced from the quite different statutes which do in fact unequivocally confer such a privilege. Compare, for example, the absolute privilege accorded to income tax records. 26 U.S.C. $\$ 55$ (1940). Sce also the rule with respect to practice in the Court of Claims that "the head of any department may refuse and omit to comply with any call for information or papers, when, in his opinion, such compliance will be injurious to the public interest." 28 U.S.C. $\$ 2507$ (1948). No such diseretion is conferred by $\$ 22$-the difference is too striking to be ignored. The attempt to read the "policy" of this rule into 5 U.S.C. $\$ 22$, as in Pollen v. Ford Instrument Co., 26 F. Supp. 583, 585 (E.D. N.Y. 1939), would judicially amend $\$ 22$, and confer a discretion there withheld. 
privilege. $^{\mathrm{st}}$ The reasons for this stand, were expressed by Judge Augustus Hand in terms of policy, without noticing Marshall's early rejection of executive self-determination of the scope of its privilege:

"It has been the policy of the American as well as of the English courts to treat the government when appearing as a litigant like any private individual. Any other practice would strike at the personal responsibility of governmental agencies, which is at the base of our institutions. The existence of governmental privileges must be established by the party invoking them and the right of government officers to prevent disclosure of state secrets must be asserted in the same zuay procedurally as that of a private individual." 66

\section{Considerations of Policy}

Implicit in the Government's analysis is the premise that administrators are more qualified by virtue of their expertise to judge whether publication of a particular document would be detrimental to the public interest. ${ }^{.7}$

55. For this Government brief cited United States v. Andolschek, 142 F.2d 503 (2d Cir. 1944) ; United States v. Krulewitch, 145 F.2d 76 (2d Cir. 1942); United States v. Beckman, 155 F.2d 580 (2d Cir. 1946); United States v. Grayson, 166 F.2d 863 (2d Cir. 1948); United States v. Coplon (D.C. D.C., Criminal No. 381-49, 1949); United States ex rel. Touhy v. Ragen, 180 F.2d 321 (7th Cir. 1950). Brief, supra note 14, at 7-8, n. 2. See also cascs cited, notes 21 and 22 supra.

The Government cited the following cases where the privilege had been "honorcd": Pacific-Atlantic S.S. Co. v. United States, 175 F.2d 632 (4th Cir. 1949); Ex parte Sackett, 74 F.2d 922 (9th Cir. 1935); United States v. Kohler Co., 9 F.R.D. 289 (E.D. Pa. 1949). In the Pacific-Atlantic case the Court affirmed a denial of a motion to produce records of a Navy Court trial without assigning any reason. The Sackett case, which antedates the Rules, involved a private litigation and turned on the force of a departmental regulation which was not "inconsistent with law." The Kohler case turned on the common law privilege for informers. Similar cases are United States v. Decre \& Co., 9 F.R.D. 523 (D. Minn. 1949) ; United States v. Sun Oil Co., 19 U.S.L. WeEk 2090 (Pa., 1950). Tho Government's broad claim of privilege was recognized in Walling v. Comet Carriers, 3 F.R.D. 442 (S.D. N.Y. 1944), and United States v. Brooks, 51 F. Supp. 974 (D. N.J. 1943). Cf. Pollen v. Ford Instrument Co., 26 F. Supp. 583 (E.D. N.Y. 1939).

56. Bank Line v. United States, 163 F.2d 133, 138 (2d Cir. 1947) (emphasis supplied). See also Jones v. Watts, 142 F.2d 575, 577 (5th Cir. 1944) ; United States v. Alexander, 47 F. Supp. 900, 907 (W.D. Va. 1942) ; Henz v. United States, 9 F.R.D. 291, 294 (N.D. Cal. 1949).

Under the Model Code of Evidence, A.L.I. (1942), the power is likewise reserved to the courts. Rule 227 provides that a "witness has a privilege to refuse to disclose a matter on the ground that it is a secret of state . . . unless the judge finds that the matter is not a secret of state." Cf. Model Code Rule 228.

57. Lord Dunedin summarized this argument when he stated that whether "the publication of a document is or is not detrimental to the public service depends so much upon the various points of view from which it may be regarded, and I do not think the court is in possession of these various points of view." Lord's Comm'rs of the Admiralty v. Aberdeen Steam Trawling \& Fishing Co., Ltd. [1909] S.C. 335, 340-41. Lord Chancellor Simon has said, in holding conclusive an administrator's judgment not to disclose, that preliminary judicial inspection would violate the rule against reading a communication which is withheld from the other party. Duncan v. Camell Laird [1942] A.C. 624. But in discovery 
This assumes that it is impossible to brief the court adequately on such matters-a dubious assumption. The problems involved do not transcend the vast range of complexities which are constantly submitted to the courts. Patent cases, for example, illustrate the frequent judicial determination of technical issues of great moment.

More serious than the possibility of over-complexity is the consideration that the national security will be threatened if federal agencies are not free to withhold information altogether. The assumption here is that protection of government secrets cannot safely be entrusted to the judiciarythat a judge will be less zealous than an administrative officer in preserving official secrets. That assumption is at war with the unique respect the judiciary enjoys. Then too, private industry has often been compelled to disclose secret processes and the like and to rely for protection on the court's discretion. ${ }^{58}$ Disclosure to the courts does not spell widespread disclosure; if the documents are privileged-as are official secrets-they will be withheld by the courts from private litigants and the general public.50

To insist that the Government disclose relevant documents to the court is not to disparage administrative expertise. Normally only preliminary jurisdiction and not finality is claimed for administrators, and this in a case where the agency is an arbiter without a stake in the outcome. If an administrative agency could be relied upon to weigh wisely and impartially the total public interest against its own convenience, ${ }^{\mathrm{c} \theta}$ it might then be

cases the excluded party welcomes ex parte communication in preference to the opponent's exclusive power to decide.

58. See E. I. duPont de Nemours Powder Co. v. Masland, 244 U.S. 100, 103 (1917), a suit to enjoin disclosure of trade secrets, where Justice Holmes pointed out that "the judge who tries the case will know the secrets, and if . . . in the opinion of the trial judge, it is or should become necessary to reveal the secrets to others, it will rest in the judge's discretion to determine whether, to whom, and under what precautions the revelation should be made" Cf. John T. Lloyd Laboratories, Ine. v. Lloyd Bros. Pharmacists, 131 F.2d 703, 707 (6th Cir. 1942) ; 1 Callasann, Unfair Colspetition and Trade Mlarks 714 (1945).

59. In approving the trial court's dismissal of the cause for non-compliance with the production order in United States v. Cotton Valley Operators Committee, notes 14 and 16 supra, Professor Moore has stated that "the court adopted a course of action that fairly" safeguarded any legitimate interest the government as litigant had in maintaining the secrecy of the documents-the government documents were first to be submitted to the court, and if it sustained the government's claim the defendants would not have had access to the documents and the information." 4 MfOore's Feneral Practice 1178 (2d ed. 1950).

60. "I do not think that it is out of place to indicate the sort of grounds which would not afford to the Minister adequate justification for objecting to production. It is not a sufficient ground that the documents are 'State documents' or 'official' or are marlied 'confidential:' It would not be a good ground that if they were produced the consequences might involve the department of the government in parliamentary discussion or in public criticism, or might necessitate the attendance as witnesses or otherwise of officials who have pressing duties elsewhere. Neither would it be a good ground that production might tend to expose a want of efficiency in the administration or tend to lay a department open to claims for compensation. In a word it is not enough that the department does not want to have the document produced. The minister in deciding whether it is his duty to object should bear these considerations in mind, for he ought not to take the responsibility of withholding 
supererogatory to insist on judicial review. But one must consider the matter in the framework of administrative realities. The diffusion of power in great agencies often lodges actual responsibility in the fourth or fifth tier of the administrative hierarchy. A subordinate immediately concerned with a case may not bring to it the fine objectivity of a Stimson. And the lawyers who litigate the case for the department not infrequently are as set on winning at all costs as counsel for a private litigant. To make the "head" of a department the ultimate arbiter of disclosture is, under the circumstances, no guarantee that the determination will be founded upon sound principles of national interest. ${ }^{61}$ Nor does the record of unflagging departmental opposition to disclosure on any and all grounds conduce to confidence in administrative impartiality on this score.

Entrust the administrators with exclusive power to determine which facts shall be divulged, said Wigmore, and the gate to unlimited extension of the privilege categories is open. ${ }^{22}$ Such extension not only conflicts with the Supreme Court's admonition that a privilege "should be restricted to its narrowest bounds", ${ }^{63}$ but it violates the more fundamental axiom that no party should ever be permitted to be judge in his own cause.

\section{The Government as a Third Party}

The power to withhold governmental records in private litigation was given early judicial recognition in Boske v. Comingore. ${ }^{64}$ The State of

production except in cases where the public interest would otherwise be damnified-e.g., where the disclosure would be injurious to national defence, or to good diplomatic relations, or where the practice of keeping a class of documents secret is necessary for the proper functioning of the public service." Lord Chancellor Simon, in Duncan v. Camell Laird [1942] A.C. 624,642 .

61. In cases involving Atomic Energy secrets it has been suggested that a Commissioner submit to the court an affidavit assigning reasons for non-disclosure. Haydock, Some Evidentiary Problems Posed by Atomic Energy Security Requirements, 61 Harv, L. Rev. 468, 477 (1948). But this does not obviate the objection that "interested" subordinates will in fact make the decision. Perhaps Atomic Energy secrets are anyway in a scparate category by virtue of the provision that the Commission shall "control the dissemination of restricted data in such a manner as to assure the common defense and security." 42 U.S.C.A. SuPP. $\$ 1810$ (1946).

See rejection of privilege claim for investigation by Navy Board of Inquiry, Cresmer v. United States, 9 F.R.D. 203 (E.D. N.Y. 1949) ; but see Pollen v. Ford Instrument Co., 26 F. Supp. 583, 585 (E.D. N.Y. 1939).

62. 8 WIGMIORE, EvidenCE $\$ 2379$ (3d ed. 1940).

63. Hickman v. Taylor, 329 U.S. 495, 506 (1947). In considering any extension of the privilege categories, it is well to bear in mind the words of Professor Morgan : "So scrious an interference with rational inquiry can be justified only by accompanying social benefits of high worth. . . . If a privilege to suppress the truth is to be recognized at all, its limits should be sharply determined so as to coincide with the limits of benefits it creates. In many decisions this principle is disregarded. Sentiment serves for judgment, and rhetoric is substituted for reason." Foreword, A.L.I. MODEL CODE OF EvidencE 7 (1942).

64. 177 U.S. 459 (1900). The rule is now considered well settled. Sec United States v. Andolschek, 142 F.2d 503, 506 (2d Cir. 1944). 
Kentucky had filed a tax collection suit against a private person and subpoenaed records held by the Collector of Internal Revenue. Upon the Collector's refusal to produce certain files which had been declared confidential by the Secretary of the Treasury, he was held in contempt. The Treasury had promulgated a regulation under the authority of what is now 5 U.S.C. $\$ 22$ forbidding the disclosure of Internal Revenue documents. The Supreme Court noted that the statute authorized the Secretary to promulgate regulations "not inconsistent with law," and it concluded that

"There is certainly no statute which expressly or by implication forbade the adoption of such a regulation. This being the case, we do not perceive upon what ground the regulation can be regarded as inconsistent with law." ${ }^{\text {"65 }}$

The Boske doctrine should be re-examined in the light of the changes wrought by the discovery rules-which have the force of law. Their adoption, therefore, has produced the inconsistency found to be lacking in the Boske case. Rule 26 authorizes any party to

"take the testimony of any person . . . for the purpose of discovery or for use as evidence in the action or for both purposes."

No exemption from this rule is conferred upon the Government. Rule 26 likewise authorizes the use of subpoenas as provided in Rule 45. Subparagraph $B$ of that rule in turn authorizes a demand for the production of documents. In consequence, an administrative regulation forbidding the production of documents in response to a demand made under these rules would be "inconsistent with law."

It has long been considered that all persons have a duty to produce relevant evidence, upon the assumption that the interest of the public in seeing that justice is done out-weighs the right to privacy. ${ }^{\text {co }}$ The Rules have merely underscored that duty. Not infrequently a witness may be called and questioned for weeks in a case which does not immediately touch his interests. A corporation may be called upon to produce voluminous records and files reaching back over the years at great expense and inconvenience. The plea of administrative inconvenience to the Government stands on no higher plane. The needs of justice out-weigh considerations of convenience. ${ }^{67}$

To be sure, some of the policy considerations existing where the Government is a litigant are inoperative in a private litigation. There is less

65. Id. at 469. See also Ex parte Sackett, 74 F.2d 922 (9th Cir. 1935). It may be noted that the information sought in Boske v. Comingore had been reported under compulsion of law and was probably privileged.

66. 8 WIGMORE, EVIDENCE $\$ 2192$ (3d ed. 1940).

67. The information most frequently desired-tax returns and the like-is delivered under compulsion of law and is privileged. 
danger of arbitrary suppression where the Government has no stake in the outcome, and since it does not seek discovery, fair play does not demand that it grant discovery. But the terms of the third party subpoenadeposition provisions are unqualified, and no considerations of policy can afford an exemption to the Government, though they might have some bearing upon the measure of the asserted privilege.

\section{ConcLusion}

At the base of the discovery procedure lies the conviction that pre-trial knowledge of all the facts is essential to an enlightened judicial system. Suppression of evidence has little to commend it on any theory, and it is even less defensible when the Government litigates with its own citizens. No exemption was conferred on the United States from the broad coverage of the discovery provisions. The Rules thus follow our tradition that the Government proceeds like any other litigant. ${ }^{68}$

The claim of statutory immunity represents an attempt to amend the Rules under the guise of interpretation. Historically, the claim of executive immunity founders upon the rulings of Chief Justice Marshall in the Burr case. It harks back to a royal prerogative which found scant favor on our soil and, even in the field of "sovereign immunity", is regarded with increasing disfavor. In a State that rests on the consent of the governed, the claim of the Government to greater privileges than are accorded its citizens must rest not on administrative convenience, not on archaic notions of prerogative alien to our institutions, but on genuine necessity. Our nation has again and again risen above partisan strife because of general confidence in the fairness of the Government. That confidence is indispensable to continuance of our democratic institutions. It can only be impaired by governmental claims of special privilege against the citizenry.

68. See Bank Line v. United States, 163 F.2d 133, 138 (2d Cir. 1947). 


\section{THE YALE LAW JOURNAL}

\begin{tabular}{lll}
\hline VoluMe 59 & DECEMBER, 1950 & NUMarbr 8 \\
\hline
\end{tabular}

\section{EDITORIAL BOARD}
Stuart W. Thayer Editor-iit-Chicf
Willialar R. Perlis Executive Editor

$\begin{array}{cc}\text { Bernard H. Greene } & \text { Burfe Miarshall } \\ \text { William Dill Rogers } & \text { Article and } \\ \text { Comment Editors } & \text { Book Review Editor }\end{array}$

Dariter J. Frego

Ructand N. Gasdiez ROAERT K LTFTO: Note Edifors

\section{WALTER G. FARR, JR Case Editor}

CuRTIS J. Berger

HARRY F. BRAUER

JOEL L. CARR

JaAies C. Cochrane

PaUd U. Daniel

HAROLD D. FIELD, JR

Robert A. FleTCHER

StanLEy J. FriedXIAN

JOHN S. HOFFINGER

Junius Hofraran

Marie MicMahoN

Business Secretary

Subscription price $\$ 5.50$ per ycar
HeNRY L. King

Mranaging Edilor
ROBERT P. LYONS Harrold J. AicCoras Patricta A. McGowaz: Kunt W. Aferchios Dougras S. Parrozr JERONE H. RETCH HuLEN D. Wewdosp JoAr ZeLDes Ricenso A. Zumian

Canadian subscription price $\$ 6.00$ per year; Forcign, $\$ 6.25$ per year for prices on other issues istquire

The Yale Law Journal Company, 401A Yale Station, New Haz'n, Connceficut

\section{CONTRIBUTORS TO THIS ISSUE}

Charies E. Clark. B.A. 1911, LL.B. 1913, Yale University. Dean of Yale Law School, 1929-1939. Judge, United States Court of Appeals for the Sccond Circuit.

Eldas Clark. B.A. 1943, LL.B. 1947, Yale University. Assistant Professor of Law, Yale Law School.

F. S. C. Norturop. B.A. 1915, Beliot College; MI.A. 1919, Yale University; AS.A. 1922, Ph.D. 1924, Harvard University. Sterling Professor of Philosophy and Law, Yale Law School.

RAOUL BERGER. B.A. 1932, University of Cincinnati; J.D. 1935, Northyestern University; LL.M. 1938, Harvard University. Formerly General Counsel to the Alien Property Custodian. Member of the District of Columbia and Illinois Bars.

ABE KRASH. B.A. 1946, J.D. 1949, University of Chicago. Graduate Fellow, Yale Law School, 1949-1950. Member of the District of Columbia Bar. 